\title{
Research on the Influencing Factors of Customer's Purchase Intention in the Context of Content Marketing
}

\author{
Gao Danli \\ Business Administration \\ Zhejiang Gongshang University \\ Hangzhou, Zhejiang, China
}

\begin{abstract}
This paper discusses the internal mechanism of consumers' purchase intention in the context of content marketing. It is of great significance to carry out effective marketing for enterprises, improve the relationship between customers and enterprises, and achieve organizational goals. This paper proposed a conceptual framework that utilized Hovland's persuasion theory to explain the influence of different contents and relationship strength on consumer's purchase intention. The results show that the relationship strength has a significant positive effect on perceived risk; the perceived risk of weak ties group is significantly greater than the perceived risk of strong ties group; the informational-based content and the entertainment-based content all have significant positive effect on brand identity; perceived risk is negatively correlated with purchase intention; and brand identity will positively influence purchase intention.
\end{abstract}

Keywords-Content marketing; Relationship strength; Purchase intention; Perceived risk

\section{INTRODUCTION}

With the rise and popularity of social media, traditional marketing methods are losing their effectiveness a little bit, and the rigid advertisements are increasingly being resisted. Content marketing, which delivers product information through storytelling and content, has become a strategic choice for most companies. Marketing Institute Content ( CMI ) 2018 Manufacturing Content Marketing Report shows that $86 \%$ of companies have conducted content marketing, but only 14 percent of respondents believe that content marketing achieved the goals of the organization, $49 \%$ of interviewers said that the content marketing is useless. Based on this, how to improve the relationship between customers and enterprises through content marketing, what factors in the process of reading content can affect consumers' willingness to purchase, and how this factors affecting purchasing decisions become the hotspot.

Content marketing is a relatively new concept abstracted from business practice. Existing research only explores the concept of content marketing and its impact, the dimensions of content and the mechanism of influence on purchase intention are lack of analysis, ambiguous causal logic is not conducive to effective management of content marketing in practice, but

Sponsors: Major projects of philosophy and social science research base of Ministry of Education (16JJD790055). also is not conducive to the in-depth exploration of content marketing. Therefore, this paper attempts to study the influencing factors of consumers' purchase intention in content marketing by combining literature research and empirical analysis. This article hopes to clear the following through research: Firstly, ascertain dimensions of content marketing? Secondly, the impact of various dimensions of content marketing on consumers' purchase intention? Thirdly, how social networks influence consumers' willingness to purchase in the situation of content marketing. The fourth is to explore the mediating role of perceived risk and brand identity.

\section{CONCEPTUAL BACKGROUND AND MODELING}

At present, there are relatively few academic researches and theories about content marketing. Relevant articles only focus on the definition of content marketing, and the definitions of content marketing concepts are still inconsistent. However, all researches involve the information that providing contents to consumers and motivating consumers to make decisions. Therefore, content marketing can be seen as the process of information presentation and persuasion. This paper proposed a conceptual framework that utilized Hovland's persuasion theory to explain the influence of different contents and relationship strength on consumer's purchase intention.

\section{A. The impact of relationship strength on perceived risk}

Relationship strength is an important characteristic of the relationship between people. Strength of the relationship can be divided into strong ties and weak ties, strong relationship consist of family, friends, etc., relative to the weak relationship you are more willing to believe them, thus influencing attitudes and behaviors [1]. According to the strong and weak relationship theory, the strength of the relationship between content sharers and content recipients will affect consumers' attitudes and emotions. Compared with weak relationships, consumers believe that the information obtained through strong relationships is more trustworthy. That is, the relationship between the content sharer and the content recipient affects the perception of risk. People who have strong ties believe that the other party will care about their interests and the perceived risk is low. On the contrary, people who have weak ties will assume that the other party will make irresponsible behavior for the 
economic benefit, and the perceived risk is higher. Therefore, we hypothesize that:

H1a: the strength of the relationship between users positively affects the perceived risk;

H1b: the perceived risk of the weak ties group is significantly greater than the perceived risk of the strong ties group.

\section{B. The impact of content types on brand identity}

Content marketing provides information to consumers. For consumers, this information is high quality, educational, and helpful in purchasing decisions. Therefore, content marketing can be regarded as an extension of the enterprise service. If consumers believe that the company's service system is reliable, then the more likely they are to make decisions that are beneficial to the company, one of which may be to generate brand identity. In other words, content marketing can trigger consumers' perceptions and attitudes toward products. LEE believe that when the content (advertising) has a high correlation with brand, consumer's attitude to the brand will be enhanced. Which means, content with more brand information makes it easier for consumers to generate brand identity. Chen and Rodger (2006) pointed out that the more interesting the content is, the easier it is to accept [3]. That is to say, the interest of the content promotes consumer's brand identity. Hence, we contend that:

$\mathrm{H} 2 \mathrm{a}$ : informational content is positively affecting consumer brand identity;

$\mathrm{H} 2 \mathrm{~b}$ : entertainment content is positively affecting consumer brand identity.

\section{The impact of perceived risk on consumers' purchase intention}

Perceived risk is an important variable that influences and describes consumers' purchase intention. Ueland, Gunnlaugsdottir\&Holm. (2012) stated in the BRA model that

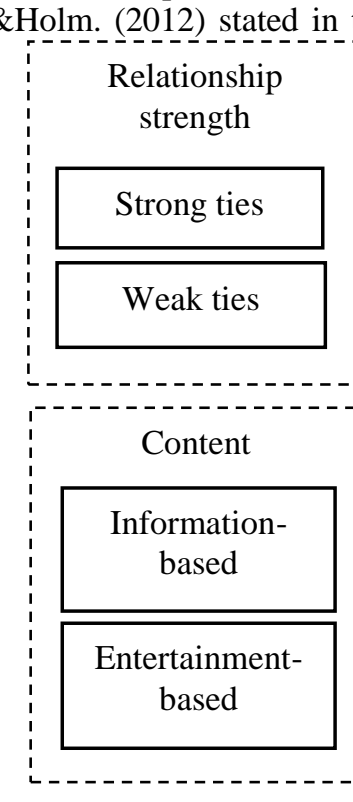

consumer perceived risk is one of the most important factors directly affecting consumers' willingness to purchase [4]. Most scholars believe that there is a negative correlation between perceived risk and consumer's willingness to purchase. In the field of online shopping, perceived risk will affect the purchasing decisions of online consumers to varying degrees? In the process of online purchasing, consumers will reduce their willingness to purchase when they expect high risk after purchase. Hense:

H3: the perceived risk of consumers has a negative impact on the willingness to purchase.

\section{The influence of brand identity on consumers' purchase intention}

Brand identity will increase consumers' desire to buy the brand. The more similar the brand and the consumer's personality are, the more the consumer has a sense of belonging, thereby enhancing the brand identity and strengthening the consumers' purchase intention. Guo (2012) also confirmed that consumer brand identity affects purchase behavior by affecting its brand loyalty [6]. The cultural identity of the brand will positively influence consumers' willingness to purchase regional brand products [7]. Therefore:

H4: consumer brand identity positively affects consumers' willingness to purchase.

\section{E. Model construction}

Based on the above theoretical analysis and research hypothesis, this paper proposed a conceptual framework to explain the influence of different content and relationship strength on consumer's purchase intention. As shown in Figure 1:

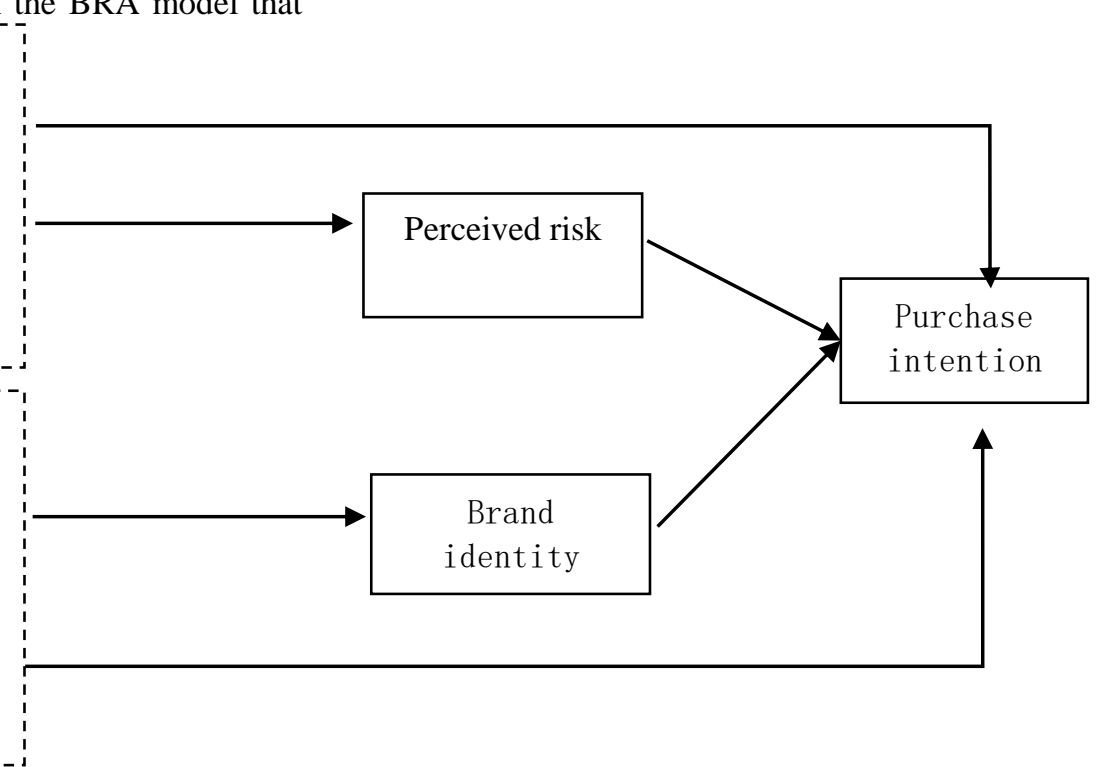

Fig. 1. conceptual model 


\section{EMPIRICAL ANALYSIS}

\section{A. Research samples and data collection}

A total of 300 questionnaires were distributed, and a total of 220 valid questionnaires were finally collected. Among the participants, males and females accounted for $53.75 \%$ and $46.25 \%$ respectively ; most participants were in the $20-30$ year age group $(83.75 \%), 31-40$ years old accounted for $11.25 \%$, and 41 years old and above accounted for $5 \%$; undergraduate education $8.75 \%$, about $61.25 \%$ have bachelor degree, $27.5 \%$ have master's degree, doctors accounted for $2.5 \% ; 16.25 \%$ participants were got paid lower than 2000yuan a month , 2001-3000yuan for $15 \%$, 3001-4000yuan for 10\% , most participants with monthly income in the above-4000yuan range $(58.75 \%)$.

\section{B. Variable measurement}

- Marketing content. Informational content and entertainment content were operationalized with an eight-item scale adapted from Wiertz Caroline (2007) [9] and Liu \& Amett (2000) [10].

- Relationship strength were operationalized with a fiveitem scale adapted from Liang\& Ho (2011) [11] and Stanko \& Bonner (2007) [12].
- Perceive risk were operationalized with a four-item scale adapted from PanWei, ZhangXing\&Gaoli (2010) [13].

- Brand identity. Personal brand identity and social brand identity were operationalized with an eight-item scale adapted from Rio (2001) [14].

- Purchase intention were operationalized with a fouritem scale adapted from Dodds (1991) [15].

\section{Data analysis}

1) Reliability and validity analysis

The reliability and validity of the sample data were tested by SPSS20.0 and AMOS22.0 statistical software. In this study, the questionnaire shows great reliability (the Cronbach's $\alpha$ coefficient of each variable is above 0.8). Then the confirmatory factor analysis is carried out. The questionnaire shows great validity: the standardized load factors of all the measured items are greater than 0.5, and the combined reliability are greater than 0.8 , AVE is greater than 0.5 except for the cognitive demand dimension, and the average extracted variance of the cognitive demand dimension is 0.451 slightly lower than 0.5 , which is still acceptable. Therefore, the model still has good polymerization validity, the square root of the AVE on the diagonal is greater than the correlation coefficient, as shown in Table I .The model and research hypothesis have certain rationality, the relationship between the variables can be further analyzed.

TABLE I. SQUARE ROOT OF AVE AND CORRELATION COEFFICIENT MATRIX

\begin{tabular}{|l|l|l|l|l|l|l|l|}
\hline \multicolumn{1}{|c|}{ variable } & RS & IBC & EBC & PR & PBI & SBI & PI \\
\hline RS & 0.796 & & & & & & \\
\hline IBC & 0.525 & 0.809 & & & & & \\
\hline EBC & 0.388 & 0.492 & 0.803 & & & & \\
\hline PR & 0.527 & - & - & 0.794 & & & \\
\hline PBI & - & 0.438 & -0.162 & - & 0.871 & & \\
\hline SBI & - & 0.218 & 0.226 & - & - & & \\
\hline PI & -0.059 & -0.038 & 0.066 & 0.096 & 0.663 & 0.269 & \\
\hline
\end{tabular}

\section{2) Hypothesis testing}

Linear regression analysis was used to analyze the relationship between relationship intensity and perceived risk. As shown in TableII, the regression coefficient of perceived risk are significant $(\mathrm{B}=0.598, \mathrm{sig}=0.004<0.05)$, indicating that the relationship intensity had a significant positive impact on perceived risk. H1a is proved.

TABLE II. LINEAR REGRESSION ANALYSIS OF RELATIONSHIP STRENGTH AND PERCEIVED RISK

\begin{tabular}{|c|c|c|c|c|c|c|c|}
\hline & \multicolumn{2}{|c|}{ Non-standardized coefficient } & Standardization coefficient & \multirow{2}{*}{$\mathbf{t}$} & \multirow{2}{*}{ Sig } & \multirow{2}{*}{$\mathbf{R}^{2}$} & \multirow{2}{*}{$\mathbf{F}$} \\
\hline & B & stanaara error & Beta & & & & \\
\hline constant & 2.947 & .120 & & 24.635 & $.000 * *$ & \multirow[b]{2}{*}{.101} & \multirow[b]{2}{*}{$8.731 *$} \\
\hline RS & .598 & .202 & .317 & 2.955 & $.004 *$ & & \\
\hline
\end{tabular}

Next, we used independent sample T test to test hypotheses H1b.As shown in TableIII, the mean value of perceived risk of consumers in the strong ties group is smaller than in the weak ties group (strong ties group: 2.9471 < weak ties group: 3.5446). And the perceived risk of the weak ties group is significantly greater than the perceived risk of the strong ties 
group (line Assume that the variances are equal, sig (two sides) $=0.004<0.05$, see TABLE IV). H1b is proved.

TABLE III. GROUP STATISTICS

\begin{tabular}{|c|c|c|c|c|c|}
\hline & Relationship strength & $\mathbf{N}$ & Mean & $\begin{array}{l}\text { Standard } \\
\text { deviation }\end{array}$ & Standard error of mean \\
\hline PR & 0 (weak tie) & 103 & 3.5446 & .84998 & .16063 \\
\hline & 1 (strong tie) & 117 & 2.9471 & .86933 & .12055 \\
\hline
\end{tabular}

TABLE IV. INDEPENDENT SAMPLE TEST

\begin{tabular}{|c|c|c|c|c|c|c|c|c|c|c|}
\hline & & \multicolumn{2}{|c|}{$\begin{array}{c}\text { Levenetest } \\
\text { of variance } \\
\text { equation }\end{array}$} & \multicolumn{7}{|c|}{$t$ test of mean equation } \\
\hline & & \multirow[t]{2}{*}{$F$} & \multirow[t]{2}{*}{ Sig. } & \multirow[t]{2}{*}{$t$} & \multirow[t]{2}{*}{$D f$} & \multirow{2}{*}{$\begin{array}{c}\text { Sig. } \\
(\text { two } \\
\text { sides ) }\end{array}$} & \multirow{2}{*}{$\begin{array}{c}\text { Mean } \\
\text { difference }\end{array}$} & \multirow[t]{2}{*}{ Mark error } & \multicolumn{2}{|c|}{$\begin{array}{l}95 \% \text { confidence interval } \\
\text { for difference }\end{array}$} \\
\hline & & & & & & & & & Lower limit & Upper limit \\
\hline \multirow{2}{*}{ PR } & $\begin{array}{c}\text { Assume that } \\
\text { the variances } \\
\text { are equal }\end{array}$ & .012 & .913 & -2.955 & 78 & .004 & -.59753 & .20222 & -1.00011 & -.19495 \\
\hline & $\begin{array}{l}\text { Assume that } \\
\text { the variances } \\
\text { are not equal }\end{array}$ & & & -2.975 & 56.493 & .004 & -.59753 & .20084 & -.99978 & -.19528 \\
\hline
\end{tabular}

Linear regression results reflected that perceived risk has a significant negative effect on purchase intention $(B=-0.586$, sig=0.000), see TABLE V, and H3 was proved. Hierarchical multiple regression result reflected that perceived risk is a partial mediator variable. After adding the mediator variable-

perceive risk, the influence of relationship intensity on purchasing intention was significantly reduced (ranging from model $1, \mathrm{~B}=0.878$, sig $=0.000$ to model $2, \mathrm{~B}=0.587$, sig= 0.001 ), see TableVI.

TABLE V. RESULTS OF LINEAR REGRESSION ANALYSIS

\begin{tabular}{|l|l|l|l|l|l|l|l|}
\hline $\begin{array}{c}\text { Dependent } \\
\text { variable }\end{array}$ & $\begin{array}{c}\text { Independent } \\
\text { variable }\end{array}$ & \multicolumn{1}{|c|}{ B } & \multicolumn{1}{c|}{ T value } & F value & $\mathbf{R}^{2}$ & Adjust R $^{2}$ & Sig. \\
\hline $\mathrm{PI}$ & $\mathrm{BI}$ & 1.020 & 12.577 & $158.189 * *$ & .670 & .666 & .000 \\
\cline { 2 - 9 } & $\mathrm{PR}$ & -.586 & 6.392 & $40.802 * *$ & .344 & .335 & .000 \\
\hline
\end{tabular}

a. $* \operatorname{sig}<0.05 * * \operatorname{sig}<0.01$

TABLE VI. HIERARCHICAL MULTIPLE REGRESSION ANALYSIS OF RELATIONSHIP STRENGTH, PERCEIVED RISK AND PURCHASE INTENTION

\begin{tabular}{|c|c|c|c|c|c|c|c|c|}
\hline & \multirow{2}{*}{ Model } & \multicolumn{2}{|c|}{$\begin{array}{l}\text { Non-standardized } \\
\text { coefficient }\end{array}$} & \multirow{2}{*}{$\begin{array}{c}\begin{array}{c}\text { Standardization } \\
\text { coefficient }\end{array} \\
\text { Beta }\end{array}$} & \multirow{2}{*}{$\mathbf{t}$} & \multirow{2}{*}{ Sig } & \multicolumn{2}{|c|}{ B 's $95.0 \%$ confidence interval } \\
\hline & & $B$ & Standard error & & & & Lower limit & Upper limit \\
\hline \multirow{2}{*}{1} & constant & 2.795 & .111 & & 25.074 & $.000 * *$ & 2.573 & 3.017 \\
\hline & $\mathrm{RS}$ & .878 & .188 & .467 & 4.659 & $.000 * *$ & .503 & 1.253 \\
\hline \multirow{3}{*}{2} & constant & 1.360 & .283 & & 4.798 & $.000 * *$ & .796 & 1.924 \\
\hline & $\mathrm{RS}$ & .587 & .170 & .312 & 3.442 & $.001 *$ & .247 & .926 \\
\hline & PR & -.487 & .091 & .487 & 5.378 & $.000 * *$ & .307 & .667 \\
\hline
\end{tabular}

Firstly, factor analysis is conducted to two-dimensional variable brand identity, then, we used factor score coefficient matrix and corresponding variance contribution to reduce the two-dimensional variable. Then, we used multi-regression to derive the relation between content and brand identity. As shown in TABLE VII, information-based content and entertainment-based content will positively influence brand identity $(\mathrm{B}=0.335$, sig=0.000; $\mathrm{B}=0.313$, sig=0.000), H2a, H2b 
are proved. Brand identity will positively affect the purchase intention $(\mathrm{B}=1.020$, sig=0.000; $\mathrm{B}=0.313$, sig=0.000), see TABLEV, $\mathrm{H} 4$ is certified. As we can see in TABLEVIII, by means of analysis of mesomeric, it can be found that brand identity is a partial mediator of information-based content to purchase intention (After adding the intermediary variable brand identity, the influence of the content on the purchase intention has changed significantly, (regression coefficient reduce from 0.469 to 0.180 ) and a complete mediator of entertainment-based information to purchase intention (regression coefficient reduce from 0.285 to 0 ).

TABLE VII. REGRESSION ANALYSIS OF CONTENT MARKETING AND BRAND IDENTITY

\begin{tabular}{|c|c|c|c|c|c|c|c|c|}
\hline & \multicolumn{2}{|c|}{$\begin{array}{c}\text { Non-standardized } \\
\text { coefficient }\end{array}$} & \multirow{2}{*}{$\begin{array}{c}\begin{array}{c}\text { Standardization } \\
\text { coefficient }\end{array} \\
\text { Beta }\end{array}$} & \multirow{2}{*}{$\mathbf{t}$} & \multirow{2}{*}{ Sig } & \multirow{2}{*}{$\mathbf{R}^{2}$} & \multirow{2}{*}{ Adjust $\mathbf{R}^{2}$} & \multirow{2}{*}{$\mathbf{F}$} \\
\hline & $B$ & $\begin{array}{c}\text { Standard } \\
\text { error }\end{array}$ & & & & & & \\
\hline constant & .312 & .241 & & 1.295 & .199 & \multirow{3}{*}{.496} & \multirow{3}{*}{.483} & \multirow{3}{*}{$37.958 * *$} \\
\hline IBC & .335 & .072 & .433 & 4.660 & $.000 * *$ & & & \\
\hline $\mathrm{EBC}$ & .313 & .076 & .383 & 4.128 & $.000 * *$ & & & \\
\hline
\end{tabular}

TABLE VIII. REGRESSION ANALYSIS OF CONTENT MARKETING, BRAND IDENTITY AND PURCHASE INTENTION

\begin{tabular}{|c|c|c|c|c|c|c|c|c|}
\hline & \multirow{2}{*}{ model } & \multicolumn{2}{|c|}{$\begin{array}{l}\text { Non-standardized } \\
\text { coefficient }\end{array}$} & \multirow{2}{*}{$\begin{array}{c}\begin{array}{c}\text { Standardization } \\
\text { coefficient }\end{array} \\
\text { Beta }\end{array}$} & \multirow{2}{*}{$\mathbf{t}$} & \multirow{2}{*}{ Sig } & \multicolumn{2}{|c|}{$\begin{array}{c}\text { B 's } 95.0 \% \text { confidence } \\
\text { interval }\end{array}$} \\
\hline & & $\boldsymbol{B}$ & $\begin{array}{l}\text { Standard } \\
\text { error }\end{array}$ & & & & Lower limit & Upper limit \\
\hline \multirow{2}{*}{1} & Constant & 1.475 & .316 & .519 & 4.667 & $.000 * *$ & .846 & 2.104 \\
\hline & EBC & .528 & .099 & & 5.356 & $.000 * *$ & .332 & .724 \\
\hline \multirow{3}{*}{2} & Constant & .721 & .315 & .280 & 2.292 & $.025 *$ & .095 & 1.347 \\
\hline & EBC & .285 & .099 & .487 & 2.881 & $.004 *$ & .088 & .482 \\
\hline & IBC & .469 & .094 & & 5.011 & $.000 * *$ & .283 & .656 \\
\hline \multirow{4}{*}{3} & Constant & .450 & .239 & .014 & 1.882 & .064 & -.026 & .927 \\
\hline & EBC & .014 & .082 & .186 & .168 & .867 & -.150 & .178 \\
\hline & IBC & .180 & .080 & .695 & 2.249 & $.027 *$ & .021 & .338 \\
\hline & BI & .866 & .112 & .519 & 7.743 & $.000 * *$ & .643 & 1.089 \\
\hline
\end{tabular}

\section{CONCLUSIONS AND DISCUSSION}

\section{A. Research conclusions}

1) The influence of relationship strength on perceived risk

Relationship strength has a significant positive effect on Perceived risk $(\mathrm{B}=0.598$, sig $=0.004)$, and the perceived risk in weak ties group is greater than in strong ties group, H1a, $\mathrm{H} 1 \mathrm{~b}$ are proved. People who have strong ties believe that people will care about their interests and the perceived risk is low. On the contrary, people who have weak ties will assume that other people will make irresponsible behavior for the economic benefit, and the perceived risk is higher.

\section{2) The impact of content marketing on brand identity}

Both information-based content and entertainment-oriented content have a significant positive impact on brand identity, and $\mathrm{H} 2 \mathrm{a}$ and $\mathrm{H} 2 \mathrm{~b}$ are certified. Informational content positively affects brand identity $(B=0.335$, sig=0.000). Content that is more relevant to the brand contains more information that is useful to consumers, making it easier for consumers to generate brand identity. Entertainment content is positively affecting brand identity $(\mathrm{B}=0.313$, sig=0.000). Attractive, curious content makes it easier to accept and understand, and fosters a good image in the minds of consumers.

\section{3) The mediating role of brand identity}

Brand identity is a partial mediator of information-based content to purchase intention and a complete mediator of entertainment-based information to purchase intention. Bedweihy (2014) [16] confirmed that the humorous content promotes the brand identity of the customer. Contents can influence consumer behavior by affecting consumers' emotions. That is, if the brand image carried by the content meets the social status or needs of the consumer, they will be very happy about the purchase.

\section{4) The mediating role of perceived risk}

Perceived risk is a partial mediator variable on the path of relationship intensity affecting purchase intention. The strength of the relationship between customers is the degree of intimacy and frequency. In a closely related situation, people are more likely to trust. People believe that the other party will care about their own interests, and the perceived risk is low. The lower the perceived risk, the higher the willingness to buy.

\section{5) The impact of perceived risk on purchase intention}

Perceived risk has a significant negative effect on purchase intention $(\mathrm{B}=-0.586$, sig=0.000), and $\mathrm{H} 3$ was proved. In the process of purchasing, due to the uncertainty of product functions, when online consumers expect there will be high 
risks after purchase, they will reduce their willingness to purchase.

\section{6) The influence of brand identity on purchase intention}

Brand identity will positively influence the willingness to purchase $(\mathrm{B}=1.020$, sig $=0.000 ; \mathrm{B}=0.313$, sig $=0.000)$, and $\mathrm{H} 4$ is certified. When consumers agree on the value of brand and believe that a particular brand is consistent with its own values and can represent his identity, he will establish a long-term and stable relationship with the brand.

\section{B. Marketing Enlightenment}

Content marketing should become the strategy of the company. Study has shown that all dimensions in content can stimulate consumers' purchase intention. With the rise of social media, consumers purchase when reading content. Companies can no longer rely on price and sales information, but rather build long-term relationships with consumers by creating content that are valuable to consumers. Information-based content and entertainment-type content can meet consumer needs in different aspects, choose appropriate content according to the goal. Moreover, the content should in line with the brand culture, and bring value to consumers, in order to establish long-term contact with consumers.

Using social networks to spread brand content and expand brand influence. From the research, it can be found that under the content marketing situation, the relationship intensity still has an impact on the purchase intention. Therefore, in the process of content marketing, not only should we pay attention to the content related to the brand, but also pay attention to the interaction between the brand and the consumer. Through interaction, the users' information can be directly deposited into the enterprise's own platform. For professional content, brand owners can set up a reasonable incentive system to motivate customers to spread; for entertaining content, marketers can create content that is more suitable for sharing to attract consumers' attention and quickly spread.

Use content marketing to build consumer brand identity and build customer loyalty. Brand identity plays a mediating role in the path of marketing content affecting purchase intention. In the era of content e-commerce, channel, advertising and shelf competition are no longer the most important factors, the audience's acceptance is the deep-seated problem that the marketer needs to solve. Enterprises should tell the brand story through accurate consumer insights.

\section{Research limitations}

This study has certain limitations: Firstly, the samples we used is not representative, so the statements of the research may not universal; secondly, in the context of content marketing, there are still many factors that can affect purchase intention, such as information sharing mechanisms, consumer cognitive. In the future research, the influence mechanism of consumers' willingness to purchase under the content marketing situation should be expounded through more indepth theoretical and empirical analysis.

\section{REFERENCES}

[1] Kim Y A, Ahmad M A. Trust, distrust and lack of confidence of users in online social media-sharing communities[J]. Knowledge-Based Systems, 2013, 37(2):438-450.

[2] YangLi. The influence of The influence of content marketing on the willingness of customer network interaction [D].Xiamen University, 2014. (In Chinese)

[3] Chen Q, Rodgers S, He Y. A Critical Review of the E-Satisfaction Literature[J]. American Behavioral Scientist, 2008, 52(1):38-59..

[4] Ueland $\varnothing$, Gunnlaugsdottir H, Holm F, et al. State of the art in benefitrisk analysis: consumer perception.[J]. Food \& Chemical Toxicology, 2011, 50(1):67-76

[5] Zhang Yingyu,Zhang Mengjia,Wang Qiang,Ren Ying,MayangguangThe Willlingness to Buy Fresh Agricultural-Based on the Perceived Benefits-Perceived Risk Framework [J].China Soft Science magazine,2015(06):128-138. (In Chinese)

[6] Guo Guoqng,Niu Haipeng,Liu Tingting.An Empirical Study of Brand Experience on Brand Loyalty Driving Effect-Taking Different Product Intrusion Brand As an Example [J]. Economics and Management Review, 2012, 2012(2):58-66. (In Chinese)

[7] Ma Xiangyang,Wang Yechun. The Influence of Culture Identity on Regional Brand Purchase Intention [J]. Heibei Science and Technology, 2015, 32(1):32-37.)(In Chinese)

[8] Wang Xiuhong,Wang Rui,Ma Xiangyang.Is it useful to establish a business leader?-Study on the influence machanism of corproate leaders' brand identity on perchase intention [J].Journal of Tianjin University(Social Science),2017,(5):391-398. (In Chinese)

[9] Wiertz Caroline(2007)(Wiertz C, Ruyter K D. Beyond the Call of Duty: Why Customers Contribute to Firm-hosted Commercial Online Communities[J]. Organization Studies, 2007, 28(3):347-376.

[10] Liu C, Arnett K P. Exploring the factors associated with Web site success in the context of electronic commerce[J]. Information \& Management, 2000, 38(1):23-33.

[11] Liang T, Ho Y, Li Y, et al. What Drives Social Commerce: The Role of Social Support and Relationship Quality[J]. International Journal of Electronic Commerce, 2011, 16(2):69-90.

[12] Stanko M A, Bonner J M, Calantone R J. Building commitment in buyer - seller relationships: A tie strength perspective $[\mathrm{J}]$. Industrial Marketing Management, 2007, 36(8):1094-1103.

[13] PanWei,ZhangXing,Gaoli. Research on the influencing factors of customer's purchase intention in online situation-Based on trust and perceived risk [J]. China Industrial Economy, 2010(7):115-124. 115-124. (In Chinese)

[14] Río A B D, Vázquez R, Iglesias V. The role of the brand name in obtaining differential advantages [J]. Journal of Product \& Brand Management, 2001, volume 10(7):452-465.

[15] Dodds W B, Monroe K B, Grewal D. Effects of Price, Brand, and Store Information on Buyers' Product Evaluations[J]. Journal of Marketing Research, 1991, 28(3):307-319.

[16] Elbedweihy A M,Jayawardhena C. Consumer-brand identification: A social identity based review and research directions[J]. Marketing Review,2014,14(2):205-228. 